\title{
A Post-Keynesian macroeconomic policy mix as an alternative to the New Consensus approach
}




\title{
A Post-Keynesian macroeconomic policy mix as an alternative to the New Consensus approach*
}

\author{
Eckhard Hein $^{\#}$ and Engelbert Stockhammer ${ }^{\# \#}$
}

\footnotetext{
\# Macroeconomic Policy Institute (IMK), Hans Boeckler Foundation, Duesseldorf, Carl von Ossietzky University Oldenburg, and Vienna University of Economics and Business Administration

\#\# Vienna University of Economics and Business Administration
}

\begin{abstract}
In a Post-Keynesian (PK) model we show that inflation targeting monetary policies, as the main stabilisation tool proposed by the New Consensus Model (NCM), in the short run are only adequate for certain values of the model parameters, but are either unnecessary, counterproductive, or limited in their effectiveness for other values. Taking into account medium-run cost and distribution effects of interest rate variations renders monetary policies completely inappropriate as an economic stabiliser. Based on these results we argue that the NCM macroeconomic policy assignment should be replaced by a PK assignment. Enhancing employment without increasing inflation will be possible if macroeconomic policies are coordinated along the following lines: The central bank targets distribution between rentiers, on the hand, and firms and labourers, on the other hand, and sets low real interest rates, wage bargaining parties target inflation and fiscal policies are applied for short- and mediumrun real stabilisation purposes.
\end{abstract}

\section{Corresponding author}

PD Dr. Eckhard Hein

Macroeconomic Policy Institute (IMK), Hans Boeckler Foundation

Hans Boeckler Str. 39

40476 Duesseldorf

Germany

e-mail: eckhard-hein@boeckler.de

\footnotetext{
* For helpful comments we would like to thank Philip Arestis, Jan-Oliver Menz, and the participants in the conference 'Unemployment: Past and Present', 30 August - 1 September, 2007, Downing College, Cambridge, UK. Remaining errors are, of course, ours. The major part of the paper was written while Eckhard Hein was a visiting professor at Vienna University of Economics and Business Administration (WU). The hospitality of the WU is gratefully acknowledged.
} 
Nowadays, mainstream macroeconomics is dominated by New Consensus Models (NCMs). ${ }^{1}$ In these models there is again an impact of aggregate demand on output and employment, but only in the short run. Due to nominal and real rigidities the short-run Phillips curve is downward sloping. In the long run, however, there is no effect of aggregate demand on the 'Non Accelerating Inflation Rate of Unemployment' (NAIRU), which is determined by structural characteristics of the labour market, the wage bargaining institutions and the social benefit system. ${ }^{2}$ Therefore, the long-run Phillips curve becomes vertical. In these models, monetary policy applying the interest rate tool is able to stabilise output and employment in the short run, but in the long run it is neutral and only affects inflation (Fontana/Palacio-Vera 2007). Fiscal policy is downgraded and is restricted to support monetary policies in achieving price stability (Arestis/Sawyer 2003).

Post-Keynesians (PKs) have criticised these NCMs for a variety of reasons. Broadly summarised, the critique is related to the assumption of a stable long-run equilibrium NAIRU determined exclusively by supply-side factors to which actual unemployment can be adjusted by means of monetary policy interventions, on the one hand, and to the assumption of the independence of this NAIRU from the development of actual unemployment, and hence from effective demand and monetary as well as fiscal policies, on the other hand.

Already Sawyer (2002) argued that the NAIRU should not be considered to be a strong attractor for actual unemployment. Stability of the NAIRU has been examined closer by Stockhammer (2004) including the effects of redistribution between profits and wages on effective demand which occur when actual unemployment deviates from the NAIRU. Hein (2006a) has focussed on the effects of redistribution between capitalists and rentiers on aggregate demand, triggered by accelerating or decelerating inflation. Both authors conclude that the NAIRU is not generally stable, but that a specific demand regime is required for stability. Considering the NCM recommendation of inflation targeting monetary policies in order to adjust actual unemployment to the NAIRU, Arestis/Sawyer (2004a, 2004b, 2005, 2006), Fontana/Palacio-Vera (2007), Hein (2004, 2006a), and Palacio-Vera (2005) have argued that monetary policy interventions will not be able to constrain instability in some cases for several reasons. Finally, long-run endogeneity of the NAIRU with respect to actual unemployment, and hence to macroeconomic and monetary policies, has been related to different channels. New Keynesian authors had already pointed out to labour market hysteresis (Blanchard/Summers 1987, 1988, Ball 1999). PKs have added further channels: capital stock and productivity growth effects of investment (Rowthorn 1995, 1999, Sawyer 2002, Arestis/Sawyer

\footnotetext{
${ }^{1}$ See Clarida/Gali/Gertler (1999), Meyer (2001), and Carlin/Soskice (2006: 27-172) for NCMs.

${ }^{2}$ See Ball/Mankiw (2002), Blanchard/Katz (1997), Layard/Nickell/Jackman (1991: 361-396), and Mankiw (2001) for concepts of a NAIRU.
} 
2004a: 73-99, 2005), adaptive wage and profit aspirations (Setterfield/Lovejoy 2006, Stockhammer 2008), and distribution effects of interest rate variations (Hein 2006a).

Because of the deficiencies and the problems of NCMs, PKs have started to amend these models and have proposed alternatives. First, the inflation generation and the income generation processes have been reformulated. Some PK authors have assumed the existence of a short-run inflation barrier and hence the NAIRU away (Atesoglu/Smithin 2006, Setterfield 2004, 2006a, 2006b), whereas others have accepted that there is such a short-run inflation barrier, which, however, is endogenous in the medium to long run through different channels (Lavoie 2004, 2006, Hein 2006a, Stockhammer 2008). Some authors have accepted the interest rate inverse IS-curve from the NCM (Atesoglu/Smithin 2006, Lavoie 2004, 2006, Rochon/Setterfield 2007-8a, Setterfield 2004, 2006a), whereas others have replaced it by a more elaborated PK/Kaleckian approach to effective demand allowing for real debt and different distribution effects (Hein 2006a, Rochon/Setterfield 2007-8b, Setterfield 2006b, Stockhammer 2008).

Second, different economic policy conclusions, in particular with respect to monetary policies, have been drawn. Whereas some authors have argued that central banks' inflation targeting is generally compatible with PK analysis (Fontana/Palacio-Vera 2007, Palley 2006, Setterfield 2006a), but have demanded a higher emphasis on real stabilisation and more adequate inflation targets, others have rejected any fine tuning by means of interest rate policies and have rather been in favour of stabilising the interest rate at some growth and employment conducive level (Gnos/Rochon 2007, Lavoie 1996a, Smithin 2004, Rochon/Setterfield 2007-8a, 2007-8b, Setterfield 2006b, Wray 2007). From this perspective it follows that nominal stabilisation should be delegated to wage or incomes policies (Arestis 1996, Davidson 2006, Hein 2002, 2004, 2006a, Kriesler/Lavoie 2007), and that fiscal policies should be in charge of real stabilisation in the short and in the medium to long run (Arestis/Sawyer 2003, 2004a, 2004c, Gnos/Rochon 2007).

What is lacking in the PK discussion so far is a basic but general PK synthesis model, which allows for a short-run inflation barrier, which captures the major causes for the short-run instability of the inflation barrier and hence the NAIRU, into which the major channels of medium- to long-run endogeneity of the NAIRU can be integrated, and which allows for the derivation of a complete PK macroeconomic policy-mix of monetary, fiscal and wage policies. This paper is intended to contribute to bridging this gap. Due to lack of space, however, we will not be able to integrate all the long-run endogeneity channels mentioned above. ${ }^{3}$

\footnotetext{
${ }^{3}$ For a more extensive treatment see Hein/Stockhammer (2007).
} 


\section{$2 \quad$ A basic Post-Keynesian model}

\subsection{Production, finance, distribution and the inflation generation process}

\section{Production, finance and rentiers' income}

We assume a closed economy with only rudimentary economic activity of the state. There will be no taxes and no state employment in the model, but only deficit financed government demand. Under given conditions of production, there is just one type of commodity produced with a constant coefficient technology. Assuming away overhead labour, the labour-output-ratio and hence labour productivity (y) are constant up to full capacity output given by the capital stock. The capital-potential output-ratio (v), the relation between the capital stock $(\mathrm{K})$ and potential output $\left(\mathrm{Y}^{\mathrm{v}}\right)$, is also constant. The capital stock is assumed not to depreciate. The rate of capacity utilisation ( $\mathrm{z}$ ) is given by the relation between actual and potential output. Given these assumption, the supply constraint can be written with the aid of the definition of the rate of profit, relating gross capital income $(\Pi)$ to the capital stock. The rate of profit is decomposed into the profit share (h), the rate of capacity utilisation and the inverse of the capital-potential output-ratio:

$$
\mathrm{r}=\frac{\Pi}{\mathrm{K}}=\frac{\Pi}{\mathrm{Y}} \frac{\mathrm{Y}}{\mathrm{Y}^{\mathrm{v}}} \frac{\mathrm{Y}^{\mathrm{v}}}{\mathrm{K}}=\mathrm{hz} \frac{1}{\mathrm{v}},
$$

The supply constraint is only reached by accident and the economy usually operates below maximum capacity given by the capital stock, i.e. usually: $z<1$.

The pace of accumulation is determined by entrepreneurs' decisions to invest, independently of prior savings because firms have access to credit generated by a developed banking sector ('initial finance'). We assume that long-term investment finance ('final finance') is supplied by firms' retained earnings or by long-term credit of rentiers' households (directly or through banks) (Hein 2007: chapt. 10). Introducing interest payments into the model, capital income or gross profits splits into (net) profit of enterprise $\left(\Pi_{\mathrm{F}}\right)$ and rentiers' income $(\mathrm{R})$.

$$
\Pi=\Pi_{\mathrm{F}}+\mathrm{R} .
$$

With respect to interest rate and credit, we follow the PK 'horizontalist' monetary view developed by Kaldor (1970, 1982, 1985), Lavoie (1984, 1992: 149-216, 1996b) and Moore (1989) and assume that the interest rate is an exogenous variable for the production and accumulation process, whereas the quantities of credit and money are determined endogenously by economic activity. The central bank controls the base rate of interest, commercial banks mark-up the base rate and then supply the credit 
demand they consider creditworthy at this interest rate. In what follows we consider just one interest rate as representative for the whole structure of interest rates.

Writing $i_{n}$ for the nominal rate of interest, we can define the real interest rate for given inflation expectations $\left(\hat{\mathrm{p}}^{\mathrm{e}}\right)$, the 'ex ante' real interest rate $\left(\mathrm{i}^{\mathrm{e}}\right)$, as:

$$
\mathrm{i}^{\mathrm{e}}=\mathrm{i}_{\mathrm{n}}-\hat{\mathrm{p}}^{\mathrm{e}} .
$$

The 'ex post' real interest rate, $i$, becomes endogenous to unexpected inflation $\left(\hat{\mathrm{p}}^{\mathrm{u}}\right)$ :

$$
i=i_{n}-\left(\hat{p}^{e}+\hat{p}^{u}\right)=i^{e}-\hat{p}^{u} .
$$

Firms' payments to rentiers are given by the stock of debt (B) at issue prices and the nominal rate of interest. Expected rentiers' interest income $\left(\mathrm{R}^{\mathrm{e}}\right)$ can be decomposed into a part compensating for the expected inflationary devaluation of the stock of nominal assets held by rentiers $\left(\hat{\mathrm{p}}^{\mathrm{e}} \mathrm{B}\right)$, and into expected real net income determined by the 'ex ante' real rate of interest $\left(i^{e} B\right)$. Repayment of debt is not considered explicitly:

$$
\mathrm{R}^{\mathrm{e}}=\mathrm{i}_{\mathrm{n}} \mathrm{B}=\left(\mathrm{i}^{\mathrm{e}}+\hat{\mathrm{p}}^{\mathrm{e}}\right) \mathrm{B}=\mathrm{i}^{\mathrm{e}} \mathrm{B}+\hat{\mathrm{p}}^{\mathrm{e}} \mathrm{B} .
$$

Firms' 'real' interest payments and rentiers' 'real' gross income (R) are affected whenever unexpected inflation occurs.

(6) $\quad \mathrm{R}=\left(\mathrm{i}_{\mathrm{n}}-\hat{\mathrm{p}}^{\mathrm{u}}\right) \mathrm{B}=\left(\mathrm{i}^{\mathrm{e}}+\hat{\mathrm{p}}^{\mathrm{e}}-\hat{\mathrm{p}}^{\mathrm{u}}\right) \mathrm{B}$.

The debt-capital ratio relates the stock of debt at issue prices to the capital stock at production prices and is hence given by:

(7) $\lambda=\frac{\mathrm{B}}{\mathrm{K}}$.

Since real debt effects caused by unexpected inflation are delegated to the real income flows between firms and rentiers, the debt-capital-ratio can be taken as a constant for the following analysis. 


\section{Conflicting claims, employment, unexpected inflation and distribution ${ }^{4}$}

Unexpected inflation in our model is systematically generated by inconsistent income claims of rentiers, firms and workers. ${ }^{5}$ The target gross profit share of firms $\left(\mathrm{h}_{\mathrm{F}}^{\mathrm{T}}\right)$, which has to cover retained earnings and interest payments to rentiers, is given by mark-up pricing on unit labour costs in incompletely competitive goods markets. In the short run, we assume the mark-up to be constant up to full capacity output:

$$
\mathrm{h}_{\mathrm{F}}^{\mathrm{T}}=\mathrm{h}_{0}, \quad 0<\mathrm{h}_{0} \leq 1 .
$$

If unexpected inflation arises, the realised profit share becomes:

$$
\mathrm{h}=\mathrm{h}_{0}-\mathrm{h}_{2} \hat{\mathrm{p}}^{\mathrm{u}}, \quad 0<\mathrm{h}_{0} \leq 1,
$$

with $h_{2}$ denoting the effect of unexpected inflation on the realised profit share. The higher $h_{2}$, the less effective are firms in protecting the profit share against unexpected inflation caused by external shocks or workers' wage aspirations.

The target wage share of workers $\left[\mathrm{W}_{\mathrm{W}}^{\mathrm{T}}=(1-\mathrm{h})_{\mathrm{W}}^{\mathrm{T}}\right]$ depends on the rate of employment (e), resp. unemployment $(\mathrm{u})$, because unemployment has the function to contain distribution claims of labourers (Kalecki 1971: 156-164). At this stage we assume that workers and labour unions do not consider the inflationary macroeconomic effects of their nominal wage demands and the potentially restrictive monetary policy reactions. There is neither co-ordination between unions in different firms or industries, nor between wage bargaining parties and monetary policy, with an eye to avoiding macroeconomic externalities of wage bargaining:

$$
(1-\mathrm{h})_{\mathrm{W}}^{\mathrm{T}}=\mathrm{W}_{0}+\mathrm{W}_{1} \mathrm{e}, \quad 0<\mathrm{W}_{0} \leq 1, \quad 0 \leq \mathrm{W}_{1} \text {. }
$$

We do not assume full utilisation of productive capacities given by the capital stock to be necessarily accompanied by full employment. Therefore, the employment rate is a positive function of the rate of capacity utilisation, but these two rates are not necessarily equal:

$$
\mathrm{e}=\mathrm{xz}, \quad 0<\mathrm{x} \leq 1 .
$$

\footnotetext{
${ }^{4}$ This part is developed on the basis of Stockhammer (2008) and extends the model presented there. For PK conflicting claims models of inflation see also Arestis/Sawyer (2004a: 73-87, 2005), Hein (2006a), Lavoie (1992: 391-421, 2002), Rowthorn (1977), and Sawyer (2002).

${ }^{5}$ Of course, there may also be exogenous shocks generating unexpected inflation.
} 
Whenever there is unexpected inflation, the realised wage share becomes:

$$
(1-\mathrm{h})=\mathrm{W}_{0}+\mathrm{W}_{1} \mathrm{e}-\mathrm{W}_{2} \hat{\mathrm{P}}^{\mathrm{u}}, \quad 0<\mathrm{W}_{0} \leq 1, \quad 0 \leq \mathrm{W}_{1}, \mathrm{~W}_{2},
$$

with $\mathrm{W}_{2}$ denoting the effect of unexpected inflation on the realised wage share. The higher $\mathrm{W}_{2}$, the less effective are workers in protecting the wage share against unexpected inflation caused by external shocks or firms' profit aspirations.

With adaptive expectations $\left(\hat{\mathrm{p}}_{\mathrm{t}}^{\mathrm{e}}=\hat{\mathrm{p}}_{\mathrm{t}-1}\right)$, we obtain the following short-run Phillips curve from equations (9) and (12):

$$
\hat{\mathrm{p}}_{\mathrm{t}}^{\mathrm{u}}=\Delta \hat{\mathrm{p}}_{\mathrm{t}}=\hat{\mathrm{p}}_{\mathrm{t}}-\hat{\mathrm{p}}_{\mathrm{t}-1}=\frac{\mathrm{W}_{0}+\mathrm{W}_{1} \mathrm{e}+\mathrm{h}_{0}-1}{\mathrm{~W}_{2}+\mathrm{h}_{2}},
$$

or

(13a) $\hat{\mathrm{p}}_{\mathrm{t}}=\hat{\mathrm{p}}_{\mathrm{t}-1}+\frac{\mathrm{W}_{0}+\mathrm{W}_{1} \mathrm{e}+\mathrm{h}_{0}-1}{\mathrm{~W}_{2}+\mathrm{h}_{2}}$.

In our model we have, at each point in time, a short-run inflation barrier which is similar to the NAIRU in the NCMs. With consistent income claims $(1-\mathrm{h})_{\mathrm{W}}^{\mathrm{T}}+\mathrm{h}_{\mathrm{F}}^{\mathrm{T}}=1$, we obtain from equations (8) and (10) for the stable inflation rate of employment $\left(\mathrm{e}^{\mathrm{N}}\right)$ and the NAIRU $\mathrm{u}^{\mathrm{N}}=1-\mathrm{e}^{\mathrm{N}}$ :

$$
\mathrm{e}^{\mathrm{N}}=\frac{1-\mathrm{W}_{0}-\mathrm{h}_{0}}{\mathrm{~W}_{1}}
$$

Whenever unemployment falls short of the NAIRU, inflation will accelerate because the sum of the income claims exceeds output, and unexpected inflation will arise, fuelling future inflation expectations. Whenever unemployment exceeds the NAIRU, inflation will decelerate.

Figure 1 shows the target wage shares of workers and firms as well as the realised wage as a function of employment in the upper part, and the related unexpected inflation in the lower part.

Taking into account equation (11) for the relationship between the employment rate and the rate of capacity utilisation, we obtain the following stable inflation rate of capacity utilisation $\left(\mathrm{z}^{\mathrm{N}}\right)$ :

$$
\mathrm{z}^{\mathrm{N}}=\frac{\mathrm{e}^{\mathrm{N}}}{\mathrm{x}}=\frac{1-\mathrm{W}_{0}-\mathrm{h}_{0}}{\mathrm{xW}_{1}}
$$


Figure 1

Conflicting claims, inflation and distribution

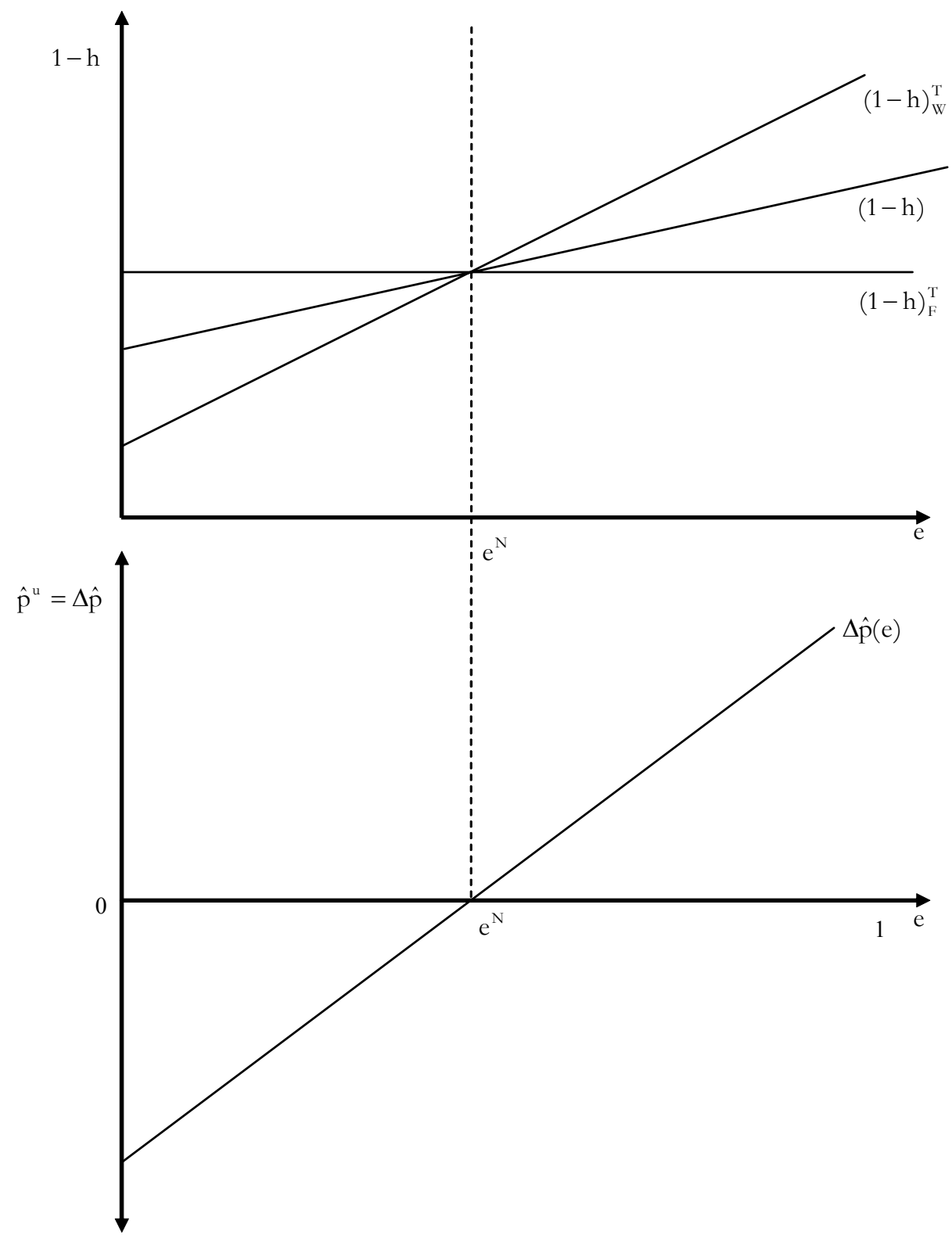




\subsection{The income generation process ${ }^{6}$}

Economic activity, and hence capacity utilisation and unemployment in our model, is determined by effective demand. For the analysis of saving and investment and the related goods market equilibrium we also assume that firms, rentiers and labourers form adaptive expectations. We assume a classical saving hypothesis, i.e. labourers do not save. The part of profits retained is completely saved by definition. The part of profits distributed to rentiers' households, i.e. the interest payments, is used by those households according to their propensity to save $\left(\mathrm{s}_{\mathrm{R}}\right)$. Therefore, total expected saving (S) comprises expected retained profits $\left(\Pi-\mathrm{i}_{\mathrm{n}} \mathrm{B}\right)$ and saving out of expected interest income $\left(\mathrm{S}_{\mathrm{R}}\right)$. Taking equations (1), (2), (5), and (7) into account, we get the private saving rate $(\sigma)$ which relates total saving to the capital stock:

$$
\sigma=\frac{\mathrm{S}}{\mathrm{K}}=\frac{\Pi-\mathrm{i}_{\mathrm{n}} \mathrm{B}+\mathrm{S}_{\mathrm{R}}}{\mathrm{K}}=\mathrm{h} \frac{\mathrm{z}}{\mathrm{v}}-\mathrm{i}_{\mathrm{n}} \lambda\left(1-\mathrm{s}_{\mathrm{R}}\right), \quad 0<\mathrm{s}_{\mathrm{R}} \leq 1
$$

For the accumulation rate (g), relating net investment (I) to the capital stock, we follow the arguments in Kalecki (1954) and assume that investment decisions are positively affected both by expected sales and by expected retained earnings. Expected sales are determined by the rate of capacity utilisation. Retained earnings, in relation to the capital stock, are given by the difference between expected profits and expected payments to rentiers normalised by the capital stock, and hence by the nominal rate of interest and the debt-capital-ratio. Taking into account equations (1), (2), (5) and (7) again, we obtain:

$$
\mathrm{g}=\frac{\Delta \mathrm{K}}{\mathrm{K}}=\frac{\mathrm{I}}{\mathrm{K}}=\mathrm{g}_{0}+\mathrm{g}_{1} \mathrm{z}+\mathrm{g}_{2}\left[\mathrm{~h} \frac{\mathrm{z}}{\mathrm{v}}-\mathrm{i}_{\mathrm{n}} \lambda\right], \quad \mathrm{g}_{0}, \mathrm{~g}_{1}, \mathrm{~g}_{2}>0, \mathrm{~g}_{2}<1
$$

We also include deficit-financed demand by the government (D) in relation to the capital stock $(\mathrm{d}=$ $\mathrm{D} / \mathrm{K})$. Government demand is exogenous for the purposes of our model:

$$
\mathrm{d}=\frac{\mathrm{D}}{\mathrm{K}}=\overline{\mathrm{d}}
$$

The goods market equilibrium is given by:

\footnotetext{
${ }^{6}$ The 'income generation process' in this paper is based on Hein (2006a, 2006b) and extends the models developed there. Rochon/Setterfield (2007-8b), Setterfield (2006b) and Stockhammer (2008) have also introduced a more elaborated income generation process than the one in the NCMs. However, they do not take fully into account the distribution effects of unexpected inflation and of changes in the interest rate on effective demand when deriving the goods market equilibrium.
} 


$$
\mathrm{g}+\mathrm{d}=\sigma
$$

and the stability condition by:

$$
\frac{\partial \sigma}{\partial \mathrm{z}}-\frac{\partial \mathrm{g}}{\partial \mathrm{z}}-\frac{\partial \mathrm{d}}{\partial \mathrm{z}}>0 \quad \Rightarrow \quad\left(1-\mathrm{g}_{2}\right) \frac{\mathrm{h}}{\mathrm{v}}-\mathrm{g}_{1}>0
$$

From equations (16) - (19), the equilibrium rate of capacity utilisation can be calculated:

$$
\mathrm{z}^{\mathrm{e}}=\frac{\mathrm{i}_{\mathrm{n}} \lambda\left(1-\mathrm{s}_{\mathrm{R}}-\mathrm{g}_{2}\right)+\mathrm{g}_{0}+\mathrm{d}}{\frac{\mathrm{h}}{\mathrm{v}}\left(1-\mathrm{g}_{2}\right)-\mathrm{g}_{1}} .
$$

Since equation (21) is based on behavioural equations which by definition can only include expected inflation, the $\mathrm{z}^{\mathrm{e}}$-equilibrium derived from these equations is a planned, or an 'ex ante' equilibrium. Taking into account the relationship between the employment rate and the rate of capacity utilisation from equation (11), we obtain the following rate of employment determined by the 'ex ante' goods market equilibrium:

$$
e^{e}=\frac{x\left[i_{n} \lambda\left(1-s_{R}-g_{2}\right)+g_{0}+d\right]}{\frac{h}{v}\left(1-g_{2}\right)-g_{1}} .
$$

\section{Is the NAIRU a strong attractor in the short run and exogenous in the long run?}

The 'ex ante' goods market equilibrium rate of employment in equation (22) may deviate from the stable inflation rate of employment determined in equation (14). Such a deviation will trigger unexpected inflation which will change distribution between total profits and wages, on the one hand, and between retained profits and rentiers' income, on the other hand. The interesting question is now whether unexpected inflation will adjust the goods market equilibrium towards the NAIRU or not. If there is no endogenous convergence towards the NAIRU, the next question is then whether an inflation targeting central bank can stabilise the system. This will be analysed in a second step. In the third step the medium- to long-run effects of variations in the interest rate triggered by central bank interventions will be briefly addressed.

In order to be able to calculate the effects of changes in the inflation rate on the employment rate, the distribution effects of unexpected inflation from equations (6) and (9) have to be included into the goods market equilibrium (22): 


$$
\mathrm{e}=\frac{\mathrm{x}\left[\left(\mathrm{i}_{\mathrm{n}}-\hat{\mathrm{p}}^{\mathrm{u}}\right) \lambda\left(1-\mathrm{s}_{\mathrm{R}}-\mathrm{g}_{2}\right)+\mathrm{g}_{0}+\mathrm{d}\right]}{\frac{1}{\mathrm{v}}\left(\mathrm{h}_{0}-\mathrm{h}_{2} \hat{\mathrm{p}}^{\mathrm{u}}\right)\left(1-\mathrm{g}_{2}\right)-\mathrm{g}_{1}} .
$$

Since unexpected inflation causes a deviation from the 'ex ante' goods market equilibrium employment rate in equation (22), equation (23) does not define an equilibrium in the behavioural sense, with expectations fulfilled. It is rather a temporary 'ex post' goods market equilibrium caused by unexpected inflation. Since there is no positive or negative excess demand in the goods market, economic agents will not change the activity level defined in equation (23), but adjust inflation expectations in the next period. However, unless the employment rate determined by the 'ex post' goods market equilibrium matches the stable inflation rate of employment, unexpected inflation will occur again, causing once more a deviation of the 'ex post' from the 'ex ante' goods market equilibrium and so on.

\subsection{The NAIRU as a strong short-run attractor without central bank interventions?}

From equation (23), the effect of unexpected inflation on the goods market equilibrium rate of employment can be derived as follows:

(23a) $\frac{\partial \mathrm{e}}{\partial \hat{\mathrm{p}}^{\mathrm{u}}}=\frac{\frac{\mathrm{h}_{2}}{\mathrm{v}}\left(1-\mathrm{g}_{2}\right) \mathrm{e}-\mathrm{x} \lambda\left(1-\mathrm{s}_{\mathrm{R}}-\mathrm{g}_{2}\right)}{\frac{1}{\mathrm{v}}\left(\mathrm{h}_{0}-\mathrm{h}_{2} \hat{\mathrm{p}}^{\mathrm{u}}\right)\left(1-\mathrm{g}_{2}\right)-\mathrm{g}_{1}}$.

First, there is redistribution between gross profits and wages affecting the goods market equilibrium, with unexpected inflation (disinflation) reducing (raising) the profit share and increasing (reducing) the wage share. Through this channel unexpected inflation (disinflation) has a positive (negative) effect on economic activity and employment, as can be seen in the first term in the numerator. Therefore, our model is unambiguously wage-led, as far as the effects of redistribution between capital and labour on capacity utilisation and employment are concerned. Taken alone, this causes a further deviation of actual unemployment from the NAIRU.

Second, there is redistribution among gross profits, with unexpected inflation (disinflation) reducing (raising) the share of rentiers' income in gross profits. The effect of redistribution between firms and rentiers on economic activity through this channel is not clear in advance, but depends on the values of the rentiers' propensity to consume and the elasticity of firms' investment with respect to internal funds. If the former exceeds the latter $\left(1-s_{R}>g_{2}\right)$, unexpected inflation and redistribution at the 
expense of rentiers has a dampening effect on economic activity ('puzzling case'). However, if the effect on firms' investment is stronger than the one on rentiers' consumption $\left(g_{2}>1-s_{R}\right.$, unexpected inflation will have a stimulating effect on economic activity and capacity utilisation ('normal case'). ${ }^{7}$

For the total effect of unexpected inflation on the 'ex post' employment rate determined by the goods market, we therefore obtain:

(23a') $\frac{\partial \mathrm{e}}{\partial \hat{\mathrm{p}}^{\mathrm{u}}}<0$, if : $1-\mathrm{s}_{\mathrm{R}}>\frac{\mathrm{h}_{2}}{\mathrm{v}} \frac{\mathrm{e}}{\mathrm{x} \lambda}\left(1-\mathrm{g}_{2}\right)+\mathrm{g}_{2}$.

The requirements for a negative effect of unexpected inflation on the goods market equilibrium rate of employment driving it towards the NAIRU are quite restrictive. We do not only need the conditions for the 'puzzling case' with respect to the macroeconomic effects of redistribution between firms and rentiers $\left(1-s_{R}>g_{2}\right)$, but also very weak demand effects of redistribution between capital and labour caused by unexpected inflation or disinflation.

If the effect of unexpected inflation on the 'ex post' goods market equilibrium is positive:

(23a'”) $\frac{\partial \mathrm{e}}{\partial \hat{\mathrm{p}}^{\mathrm{u}}}>0$, if $: \frac{\mathrm{h}_{2}}{\mathrm{v}} \frac{\mathrm{e}}{\mathrm{x} \lambda}\left(1-\mathrm{g}_{2}\right)+\mathrm{g}_{2}>1-\mathrm{s}_{\mathrm{R}}$,

Unexpected inflation will move the ex post goods market equilibrium farther away from the distribution equilibrium. This is shown in Figure 2: The initial 'ex ante' goods market equilibrium rate of employment $\left(\mathrm{e}_{1}^{\mathrm{e}}\right)$ exceeds the short-run stable inflation rate of employment $\left(\mathrm{e}^{\mathrm{N}}\right)$ which triggers unexpected inflation. Since unexpected inflation has a positive effect on the 'ex post' goods market equilibrium rate of employment, this will move the goods market equilibrium even farther away from the distribution equilibrium. With adaptive expectations economic agents will make the current inflation rate the expected rate in the next period, the 'ex ante' goods market equilibrium will move to $\left(\mathrm{e}_{2}^{\mathrm{e}}\right)$, and the 'ex post' goods market equilibrium function in employment-unexpected inflation space will shift accordingly. Unexpected inflation will be triggered again and, as a result, the goods market equilibrium will diverge monotonically from the stable inflation rate of employment.

A negative relationship between unexpected inflation and the 'ex post' goods market equilibrium rate of employment as in equation (23a'), however, is only a necessary but not yet a sufficient condition for the NAIRU to be a strong attractor. In order to make the goods market equilibrium rate of

\footnotetext{
${ }^{7}$ See Lavoie (1995) and Hein (2006b, 2007: 61-127) for a discussion of 'puzzling' and 'normal' cases in Kaleckian distribution and growth models.
} 


\section{Figure 2}

\section{The NAIRU as a non-attractor}

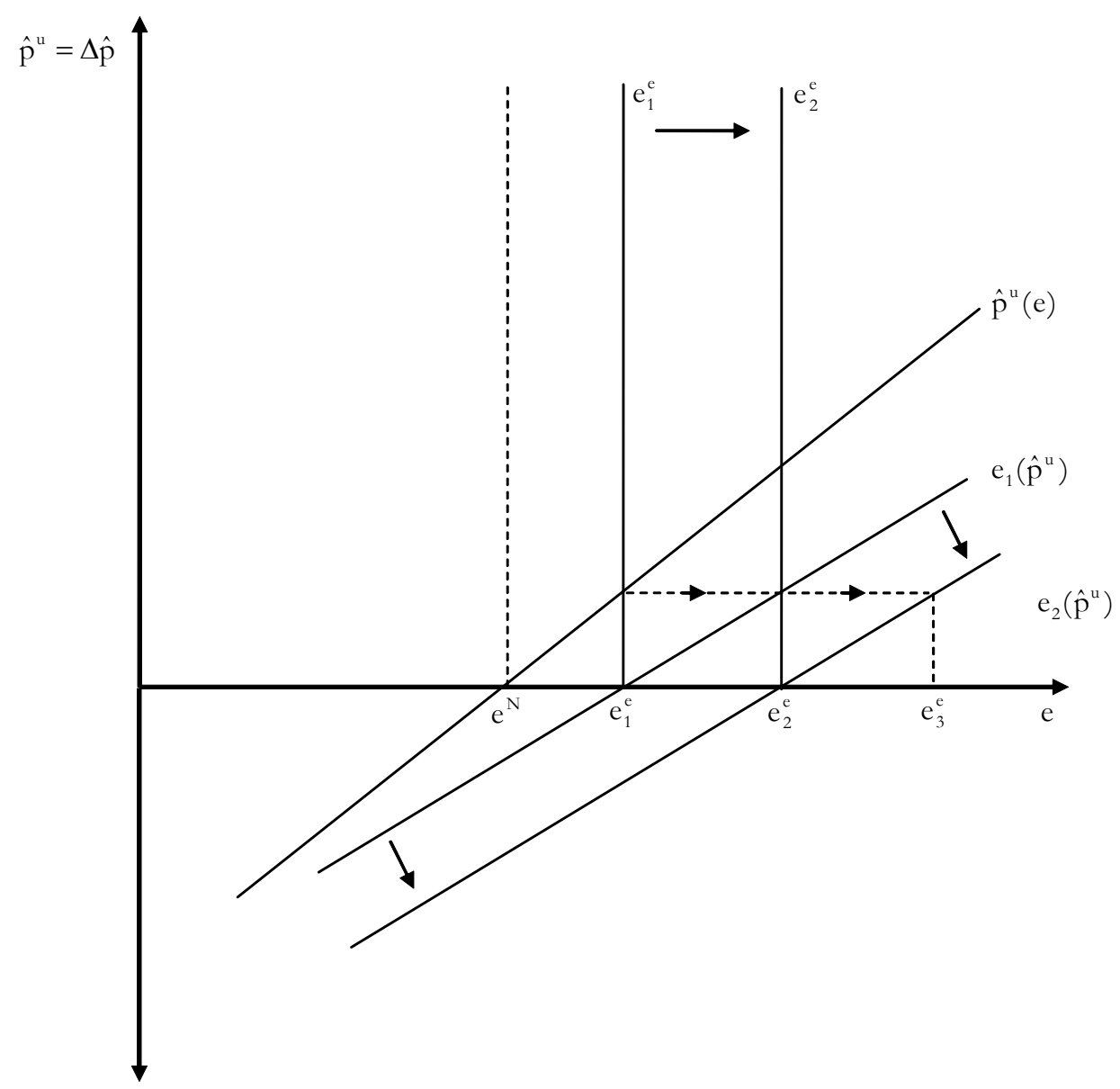

employment convergence towards the stable inflation rate, the absolute value of the slope of the "ex post' goods market equilibrium employment curve has to exceed the slope of the short-run Phillips curve, as is shown in Figure 3. ${ }^{8}$

Therefore, for the NAIRU to be a strong attractor for the actual unemployment rate, the following condition derived from equations (13) and (23) has to be valid:

(24)

$$
\frac{\frac{1}{\mathrm{v}}\left(\mathrm{h}_{0}-\mathrm{h}_{2} \hat{\mathrm{P}}^{\mathrm{u}}\right)\left(1-\mathrm{g}_{2}\right)-\mathrm{g}_{1}}{\frac{\mathrm{h}_{2}}{\mathrm{v}}\left(1-\mathrm{g}_{2}\right) \mathrm{e}-\mathrm{x} \lambda\left(1-\mathrm{s}_{\mathrm{R}}-\mathrm{g}_{2}\right)}<-\frac{\mathrm{W}_{1}}{\mathrm{~W}_{2}+\mathrm{h}_{2}} .
$$

\footnotetext{
${ }^{8}$ We may also have converging oscillations which are not shown graphically.
} 


\section{Figure 3}

\section{The NAIRU as an attractor}

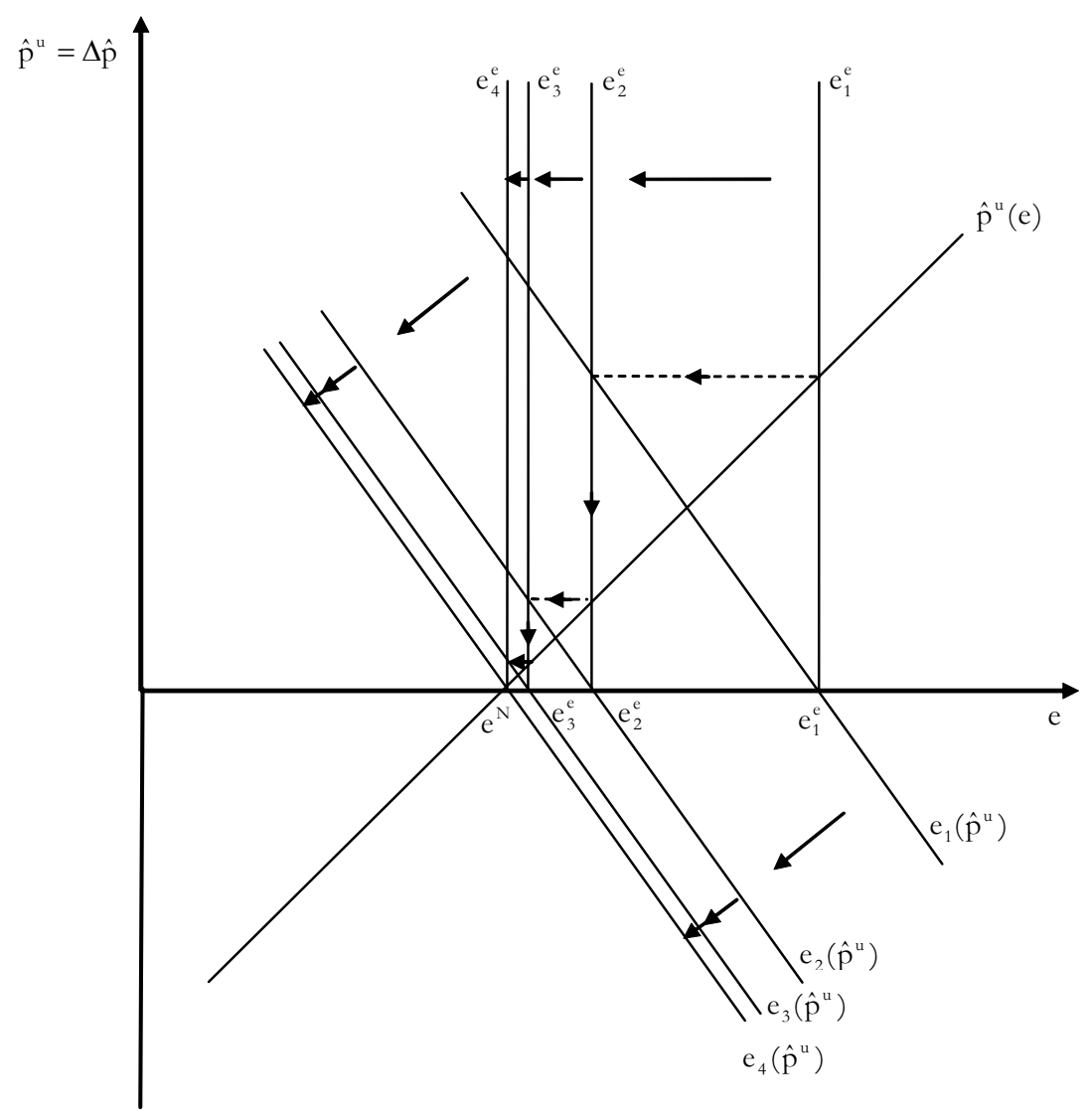

To sum up, the stability of the NAIRU requires a very low propensity to save out of rentiers' income, a very low elasticity of investment with respect to internal funds, weak redistribution effects of unexpected inflation on labour income and effective demand, and a very flat short-run Phillips curve. Since there is no economic mechanism in our model which will guarantee this very special constellation to hold, we have to discuss the role of the central bank as a stabiliser of the NAIRU next.

\subsection{An inflation targeting central bank and the NAIRU as a short-run attractor?}

Applying the NCM idea of inflation targeting by the central bank, we have to bear in mind that the central bank controls the nominal rate of interest in our model. Therefore, this is the instrument an inflation targeting central bank can apply in order to achieve some target rate of inflation $\left(\hat{\mathrm{p}}^{\mathrm{T}}\right)$. Here it is sufficient to assume that the central bank's inflation target equals expected inflation $\left(\hat{\mathrm{p}}^{\mathrm{T}}=\hat{\mathrm{p}}^{\mathrm{e}}\right)$ and 
that the only aim of the central bank is to erase unexpected inflation from the system. Therefore, the central bank reaction function becomes:

$$
\begin{aligned}
& i_{n}=i_{0}^{e}+\hat{p}^{e}+\hat{p}^{\mathrm{u}}+i_{1}\left(\hat{p}-\hat{p}^{T}\right)=i_{0}^{e}+\hat{p}^{e}+\hat{p}^{u}+i_{1}\left(\hat{p}-\hat{p}^{e}\right)=i_{0}^{e}+\hat{p}^{e}+\left(1+i_{1}\right) \hat{p}^{u}, \\
& 0 \leq i_{0}^{e}, 0<i_{1},
\end{aligned}
$$

with $i_{0}^{e}$ being the central bank's estimation of the 'equilibrium real interest rate' and $i_{1}$ the reaction parameter with respect to unexpected inflation. From equation (23) we obtain the following effect of a change in the nominal interest rate on employment determined by the goods market:

(23b) $\frac{\partial \mathrm{e}^{\mathrm{cb}}}{\partial \mathrm{i}_{\mathrm{n}}}=\frac{\mathrm{x} \lambda\left(1-\mathrm{s}_{\mathrm{R}}-\mathrm{g}_{2}\right)}{\frac{1}{\mathrm{v}}\left(\mathrm{h}_{0}-\mathrm{h}_{2} \hat{\mathrm{P}}^{\mathrm{u}}\right)\left(1-\mathrm{g}_{2}\right)-\mathrm{g}_{1}}$.

Changing the nominal interest rate will be positively related to capacity utilisation and employment, if the 'puzzling case' with respect to the demand effects of redistribution between firms and rentiers prevails:

(23b') $\frac{\partial \mathrm{e}}{\partial \mathrm{i}_{\mathrm{n}}}>0$, if : $1-\mathrm{s}_{\mathrm{R}}>\mathrm{g}_{2}$.

Inflation targeting monetary policy interventions following equation (25) will hence move employment farther away from the stable inflation level. Note that the condition in equation (23b'), indicating the inappropriateness of inflation targeting monetary policies, is not equivalent with the NAIRU being a strong attractor from equation (24). Therefore, if (23b') is valid, but (24) is not, neither is the NAIRU self-stabilising in the face of accelerating (decelerating) inflation, nor is monetary policy able to adjust actual unemployment to the NAIRU by means of raising (lowering) interest rates. In order to stabilise the NAIRU in this case, monetary policies would have to do just the opposite from what is suggested by equation (25), namely lowering (raising) the interest rate in the face of accelerating (decelerating) inflation.

If the 'normal case' with respect to the demand effects of redistribution between firms and rentiers prevails, inflation targeting monetary policies will have the required effects on economic activity and employment:

$(23 b ") \frac{\partial e}{\partial i_{n}}<0$, if : $g_{2}>1-s_{R}$. 
If unexpected inflation caused by a deviation of unemployment from the NAIRU is not self-correcting, and the condition in equation (23b") is fulfilled, the NAIRU may therefore be turned into an attractor by inflation targeting monetary policies following the monetary policy rule in equation (25). In this case, the effects of changes in the nominal interest rate have to over-compensate the effects of unexpected inflation on capacity utilisation and employment. This does not seem to be a problem with unemployment falling short of the NAIRU and positive unexpected inflation. The central bank can always increase its instrument variable, the nominal interest rate according to equation (25) and wipe out unexpected inflation by means of erasing 'excess employment' from the system. This is shown in Figure 4.

\section{Figure 4}

\section{An inflation targeting central bank}

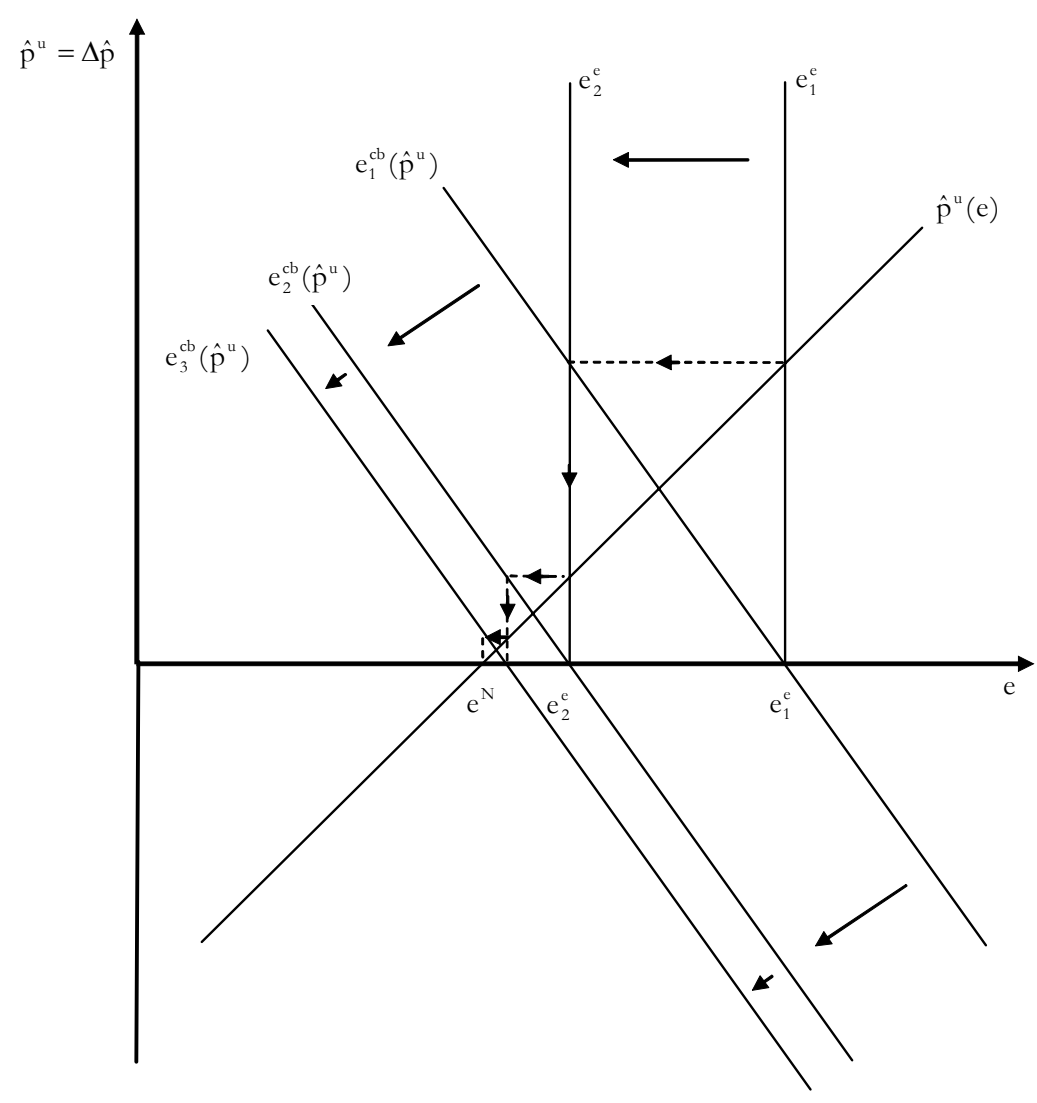

For a stable adjustment it is again required that the absolute value of the slope of the (ex post) goods market equilibrium employment curve incorporating monetary policy responses $\left(\mathrm{e}^{\mathrm{cb}}\right)$ has to exceed the slope of the short-run Phillips curve in employment-unexpected inflation space. Therefore, central banks have to be careful in their responses in order to avoid excessive over- and undershooting which would destabilise the system. 
There are further limitations for monetary policies adjusting actual employment to the stable inflation level, if unemployment exceeds the NAIRU and unexpected inflation is negative, in particular in a climate of low inflation and hence low nominal interest rates. With unexpected disinflation or even deflation, a negative nominal interest rate according to equation (25) might be required in order to stabilise the system, which central banks cannot achieve due to the zero lower bound of its instrument variable. Therefore, central banks' capacities to adjust actual unemployment towards the NAIRU may be asymmetric. ${ }^{9}$

\subsection{Medium-run endogeneity of the NAIRU through monetary policy}

So far it has been shown that inflation targeting monetary policies, as the main stabilisation tool proposed by the New Consensus Model (NCM), in the short run are only adequate for certain values of the model parameters, but are either unnecessary, counterproductive, or limited in their effectiveness for other parameter values. In this section we integrate the medium-run effects of changes in the 'ex ante' real interest associated with inflation targeting monetary policies. ${ }^{10} \mathrm{We}$ only discuss the effects of changing interest rates on the distribution equilibrium in the medium run and ignore the associated effects on the goods market equilibrium, which may give rise to complex interacting dynamics of these two equilibria. ${ }^{11}$

In Hein (2006a) it has been argued that persistent changes in the 'ex ante' real interest rate affect firms' target profit share in the medium to long run. ${ }^{12}$ Since interest payments are costs from the perspective of the firm which have to be covered by the mark-up on unit labour costs, persistent changes in the 'ex ante' real interest rate will cause medium-run changes in the firms' target mark-up. The firms' target profit share from equation (8) has therefore to be expanded with $\mathrm{h}_{1}$ denoting the medium-run interest rate effect on the target profit share:

$$
\mathrm{h}_{\mathrm{F}}^{\mathrm{T}}=\mathrm{h}_{0}+\mathrm{h}_{1} \mathrm{i}^{\mathrm{e}}, \quad 0<\mathrm{h}_{0} \leq 1, \quad 0 \leq \mathrm{h}_{1} .
$$

\footnotetext{
${ }^{9}$ Another reason for asymmetric effects of central bank policies, not explicitly discussed in our model with only one interest rate, arises from the interaction of the central bank with the commercial banking sector. Whereas the central bank can always force commercial banks to increase market rates by means of increasing the base rate, commercial banks might not follow the central bank decreasing interest rates, in particular in a recession with increasing uncertainty and risk assessments.

${ }^{10}$ Further medium- to long-run endogeneity channels of the NAIRU with respect to actual unemployment, i.e. labour market persistence mechanisms, endogenous wage and profit aspirations, and the effects of capital stock growth, cannot be treated in this paper due to a lack of space. Their integration into the present model structure is indicated in Hein/Stockhammer (2007).

${ }^{11}$ For a discussion of the related dynamics associated with a persistent change in the real interest rate in a somewhat simpler model, see Hein (2006a).

${ }^{12}$ The idea that lasting variations in interest rates may affect functional income distribution and hence the share of wages and gross profits in total income goes back to Sraffa (1960:33) and has been proposed, in particular, by Neo-Ricardian authors (see for example Pivetti 1991), but it can also be found in earlier PK work (Kaldor 1982: 63, Pasinetti 1974: 139-141).
} 
Taking into account the workers' target wage share from equation (12), we obtain the following stable inflation rate of employment:

$$
\mathrm{e}^{\mathrm{N}}=\frac{1-\mathrm{W}_{0}-\mathrm{h}_{0}-\mathrm{h}_{1} \mathrm{i}^{\mathrm{e}}}{\mathrm{W}_{1}}
$$

A persistent change in the 'ex ante' real interest rate will have an inverse effect on the stable inflation rate of employment:

(27a) $\frac{\partial \mathrm{e}^{\mathrm{N}}}{\partial \mathrm{i}^{\mathrm{e}}}=-\frac{\mathrm{h}_{1}}{\mathrm{~W}_{1}}<0$

\section{Figure 5}

Persistent change in the 'ex ante' real rate of interest and the NAIRU

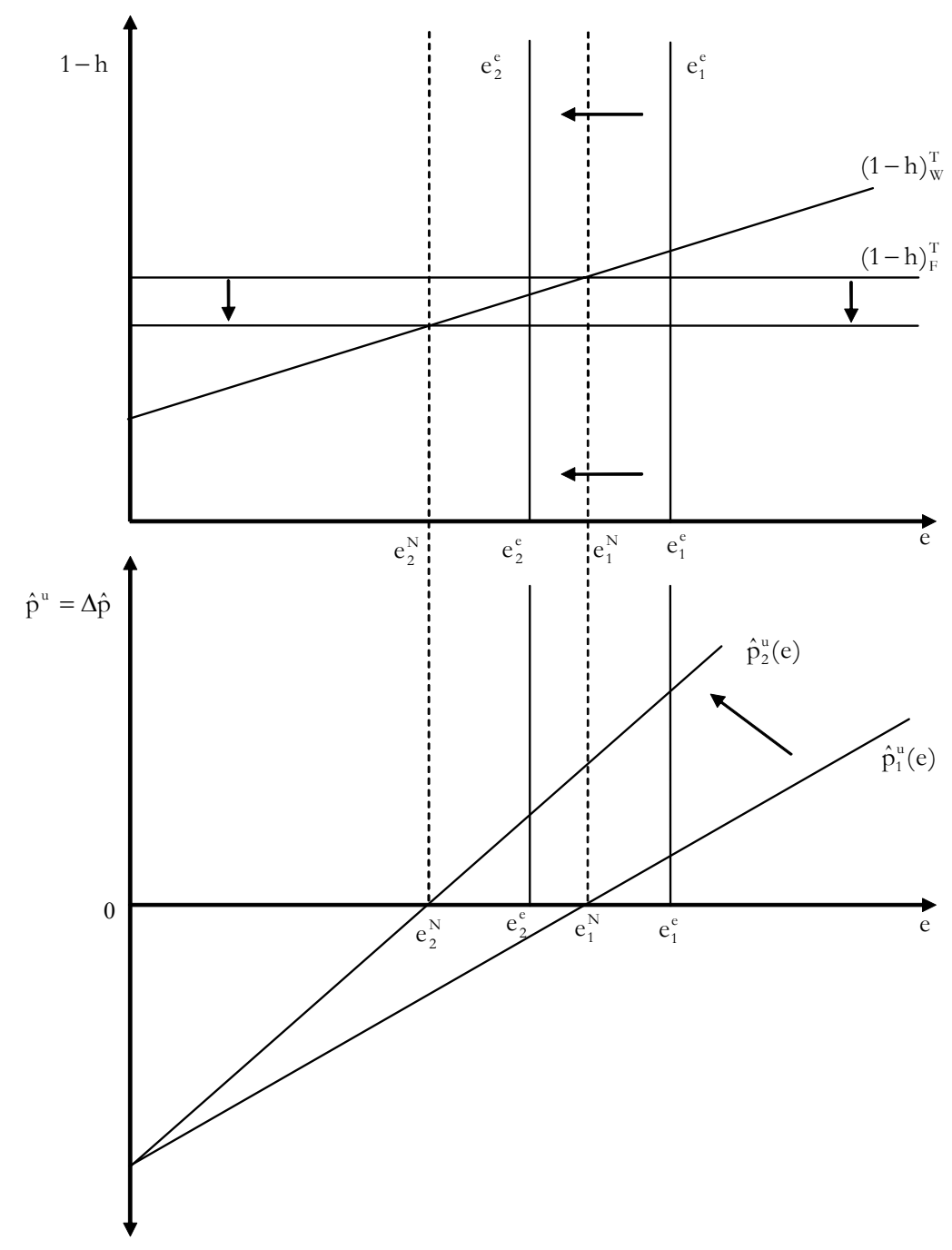


Applying the inflation targeting interest rate rule (equations 25) may therefore stabilise inflation in the short run, but in the medium run the effects on the firms' target profit share may undermine the shortrun stabilisation effects and may create unexpected inflation again, triggering further central bank intervention, as is shown in Figure 5.

\section{$4 \quad$ A Post-Keynesian macroeconomic policy assignment}

From our results so far it follows that the NCM policy assignment has to be completely revised in order to achieve a high and stable medium-run employment rate with stable inflation (expectations). Following our model, we restrict our discussion to a closed economy.

From the criticism of inflation targeting monetary policies developed above, different implications for more adequate monetary policies can be drawn. Applying the distinction made by Rochon/Setterfield (2007-8a, 2007-8b), either an 'activist' position or a 'parking-it' approach for the central bank applying the interest rate tool has been proposed by PKs. The proponents of the 'activist' position confirm the central bank's responsibility for stable inflation and regard the interest rate as an appropriate tool to achieve this goal. Therefore, PK monetary economics is held to be generally consistent with inflation targeting by central banks and with the application of an interest rate operation procedure (Fontana/Palacio-Vera 2007, Palley 2006, Setterfield 2006a). Contrary to NCMs, however, they demand more careful counter-cyclical stabilisation by means of interest rate policies, taking into account the short- and medium-run real effects, as well as more reasonable, that is higher, inflation targets. The 'parking-it' position, however, refrains from recommending fine tuning the economy by means of interest rate policies, but focuses on the long-run distribution effects of the central bank setting the interest rate, which we have highlighted above, and recommends to stabilise the long-term rate of interest at a certain level. Different targets have been proposed. Smithin (2004), for example, suggests that the real interest rate should be set to zero, or as close to zero as possible, allowing rentiers to maintain their stock of real wealth but not to participate in real growth. Lavoie (1996a) and Setterfield (2006b) are in favour of setting the real rate of interest equal to productivity growth, which allows rentiers to participate in real growth and keeps distribution between rentiers, on the one hand, and firms and labourers, on the other hand, constant (Pasinetti's (1981) 'fair rate of interest'). ${ }^{13}$ Since we have abstracted from productivity growth in our model, these two rules are essentially the same. Therefore, we obtain the following monetary policy rule:

\footnotetext{
${ }^{13}$ Wray (2007) proposes a zero nominal interest rate in order to get rid of the rentiers' class. However, this seems to imply overcoming the main characteristics of a monetary production economy, the advancement of credit in order to get production started. Obviously, with a zero nominal interest rate in a single interest rate model there is no incentive for banks/rentiers to grant credit for initial finance of production or final finance of the capital stock.
} 


$$
\mathrm{i}_{\mathrm{n}}=\mathrm{i}_{0}^{\mathrm{e}}+\hat{\mathrm{p}}^{\mathrm{e}}+\hat{\mathrm{p}}^{\mathrm{u}}
$$

with $i_{0}^{\text {e }}$ being given by medium-run productivity growth. Central banks will have to adjust their policy instrument, the nominal interest rate, so that a constant expected real rate of interest equal to mediumrun productivity growth emerges. This implies adjusting the nominal interest rate to unexpected inflation at the end of each period.

Note that monetary policies in this approach should neither pursue an inflation target nor make any attempts at adjusting the employment rate to some target. Of course, monetary policies remain responsible for the orderly working of the monetary and financial system, the definition of credit standards for refinance operations with commercial banks (credit controls), the implementation of compulsory minimum reserves of different types to be held with the central bank, the role of a 'lender of last resort' in the case of systemic crises, and so on. ${ }^{14}$

The NCM view on the role of wage formation and wage bargaining, demanding nominal and real wage flexibility by means of structural reforms in the labour market and decentralisation of wage bargaining in order to accelerate the adjustment towards the NAIRU and in order to reduce the NAIRU itself, cannot be sustained on the basis of our model. Nominal wage flexibility generates unexpected inflation whenever unemployment deviates from the NAIRU. This affects distribution between firms and rentiers, on the one hand, and between capital and labour, on the other hand, and is hence associated with real wage flexibility. With realistic parameters, nominal wage flexibility makes actual unemployment diverge further from the NAIRU in our model, as we have shown above.

In order to avoid the destabilising effects of nominal and real wage flexibility, PKs advocate rigid nominal wages and allocate the role of nominal stabilisation to incomes or wage policies. ${ }^{15}$ Therefore, nominal unit labour costs should grow at a rate similar to the country's inflation target, which means that nominal wage growth should equal the sum of medium-run growth of labour productivity $\left(\hat{\mathrm{w}}_{0}\right)$ and the target inflation rate:

$$
\hat{\mathrm{w}}=\hat{\mathrm{w}}_{0}+\hat{\mathrm{p}}^{\mathrm{T}} .
$$

Following this wage formula will also keep income shares constant, provided that the mark-up in firms' pricing remains constant and that imported material costs in an open economy grow in line with

\footnotetext{
${ }^{14}$ This view is shared by the PK proponents of the 'activist' position (see for example Palley 2006) and of the 'parking-it' position (see for instance Lavoie 1996a). A detailed discussion of central bank reactions towards financial market instabilities is outside the scope of the present contribution.

${ }^{15}$ See, for example, Arestis (1996), Davidson (2006), and Setterfield (2006a).
} 
domestic unit labour costs (Kalecki 1954: 28-30). Under these conditions, the destabilising effects of real wage flexibility in wage-led economies will be avoided, too.

The optimal way to achieve nominal stabilisation is to make the target wage shares of workers and firms compatible for a relevant range of employment rates. In the context of our model this requires to reformulate the workers target wage share from equation (10):

$$
(1-\mathrm{h})_{\mathrm{W}}^{\mathrm{T}}=\mathrm{W}_{0}+\mathrm{W}_{1} \mathrm{e}, \text { if: } \mathrm{e}<\mathrm{e}_{1}^{\mathrm{N}} \text { or } \mathrm{e}_{2}^{\mathrm{N}}<\mathrm{e},
$$

(30) and

$$
(1-\mathrm{h})_{\mathrm{W}}^{\mathrm{T}}=(1-\mathrm{h})_{\mathrm{F}}^{\mathrm{T}}=\mathrm{h}_{0} \text {, if: } \mathrm{e}_{1}^{\mathrm{N}}<\mathrm{e}<\mathrm{e}_{2}^{\mathrm{N}} \text {. }
$$

The stable inflation rate of employment and hence the NAIRU becomes a corridor and the Phillips curve from equation (13) becomes a horizontal line between $\mathrm{e}^{\mathrm{N}}{ }_{1}$ and $\mathrm{e}^{\mathrm{N}}$ (see Figure 6):

$$
\hat{\mathrm{p}}_{\mathrm{t}}^{\mathrm{u}}=\frac{\mathrm{W}_{0}+\mathrm{W}_{1} \mathrm{e}+\mathrm{h}_{0}-1}{\mathrm{~W}_{2}+\mathrm{h}_{2}}, \text { if: } \mathrm{e}<\mathrm{e}_{1}^{\mathrm{N}} \text { or } \mathrm{e}_{2}^{\mathrm{N}}<\mathrm{e}
$$

and

$$
\hat{\mathrm{p}}_{\mathrm{t}}^{\mathrm{u}}=0 \text {, if: } \mathrm{e}_{1}^{\mathrm{N}}<\mathrm{e}<\mathrm{e}_{2}^{\mathrm{N}} \text {. }
$$

Variations in the employment rate between $\mathrm{e}^{\mathrm{N}}{ }_{1}$ and $\mathrm{e}^{\mathrm{N}}{ }_{2}$ do not trigger any unexpected inflation and hence no cumulative processes will set in. In this case, demand management is free to choose a high level of employment close to $\mathrm{e}^{\mathrm{N}}{ }_{2}$ without violating stable inflation rates. PKs argue that in particular a high degree of wage bargaining coordination at the national level, strong labour unions and employer organisations, and hence organised labour markets should be particularly suitable for pursuing this nominal stabilisation role of wage bargaining. ${ }^{16}$

Because of the associated with real and nominal stabilisation by means of monetary policies, the complete neglect of discretionary fiscal policies in the NCM turns out to be a major problem (see in particular Arestis/Sawyer 2003, 2004a, 2004c). ${ }^{17}$ Therefore, PKs have argued in favour of real stabilisation by means of fiscal policies. This has again two dimensions: Since an adjustment of actual unemployment to a NAIRU cannot generally be expected, neither from market forces nor from monetary policies, fiscal policies are required for short-run real stabilisation. And since the NAIRU is

\footnotetext{
${ }^{16}$ See Hein (2006a) and Kriesler/Lavoie (2007) for the implementation of coordinated wage bargaining into PK models and Hein $(2002,2004)$ for reviews of the related literature.

${ }^{17}$ For the inappropriateness of this view, also within a NCM framework, see Setterfield (2007), who shows that also within the NCM framework there is good reason to conclude that '.. . fiscal policy is at least as, if not, more potent as an instrument of stabilization policy than is monetary policy ...' (Setterfield 2007: 417, italics in the original).
} 
endogenous to actual unemployment and hence to effective demand in the medium to long run, fiscal policies do not only have short-run real effects but also affect the long-run development of the economy.

Arestis/Sawyer (2003) demonstrate that the major arguments put forward against a use of discretionary fiscal policies, 'crowding out' (through higher inflation and associated real balance effects or higher real interest rates) and the 'Ricardian equivalence theorem', are unconvincing, both on theoretical and empirical grounds. Both arguments have to assume that the economy operates at full employment equilibrium level. But if there is already full employment, there is no need to implement expansionary fiscal policies in order to achieve full employment and hence there is no need to think about 'crowding out' or 'Ricardian equivalence'! Making use of government deficit spending for stabilising effective demand in the short and in the medium to long run, in the sense of 'functional finance', that is compensating private sector full (or stable inflation rate of) employment saving by government deficit spending, ${ }^{18}$ however, requires that central banks do not interfere with expansionary fiscal policies and stick to a policy of low interest rates.

In the context of our model real stabilisation should therefore be delegated to fiscal policies and equation (18) can be extended in the following way:

$$
\mathrm{d}=\mathrm{d}_{0}+\mathrm{d}_{1}\left(\mathrm{e}^{\mathrm{T}}-\mathrm{e}\right), \quad 0 \leq \mathrm{d}_{0}, 0<\mathrm{d}_{1},
$$

with $\mathrm{d}_{0}$ as permanent government deficit spending, which is required if employment is at target $\left(\mathrm{e}^{\mathrm{T}}\right)$, and $d_{1}$ as the reaction in the case of deviations of employment from target. The employment target is the maximum employment rate achievable without triggering unexpected inflation.

The PK assignment or policy-mix and its effects can finally be seen in Figure 6. Wage policies, and hence wage bargaining parties, are mainly responsible for stable inflation rates, and hence for nominal stabilisation. Fiscal policies are responsible for the management of demand, maintaining effective demand at high employment levels, and hence for real stabilisation in the short and in the long run. Monetary policies by the central bank should neither aim at fine tuning the economy in real nor in nominal terms, and should thus not interfere with the tasks of wage and fiscal policies, but should rather focus on stable distribution between rentiers, on the one hand, and firms and labourers, on the

\footnotetext{
${ }^{18}$ The 'functional finance' view, pioneered by Lerner (1943), recommends government deficits, the difference between government spending $(\mathrm{G})$ and taxes $(\mathrm{T})$, to mop up the excess of private sector planned saving $(\mathrm{S})$ over planned investment (I), plus the difference between imports (M) and exports (X), at a desired (full employment) level of economic activity: G-T = S-I+M-X (see Arestis/Sawyer 2004c). Applying government deficit spending in the 'functional finance' way assures that there is always enough saving to fund government deficits by means of issuing bonds and/or increasing the central bank's money supply, buying government bonds through open market operations.
} 
other hand, in order to avoid destabilising distribution effects of changes in the interest rate. Coordination of macroeconomic policies along these lines will be more promising for high employment and stable inflation rates than the NCM economic policy approach.

\section{Figure 6}

\section{A Post-Keynesian macroeconomic policy mix}

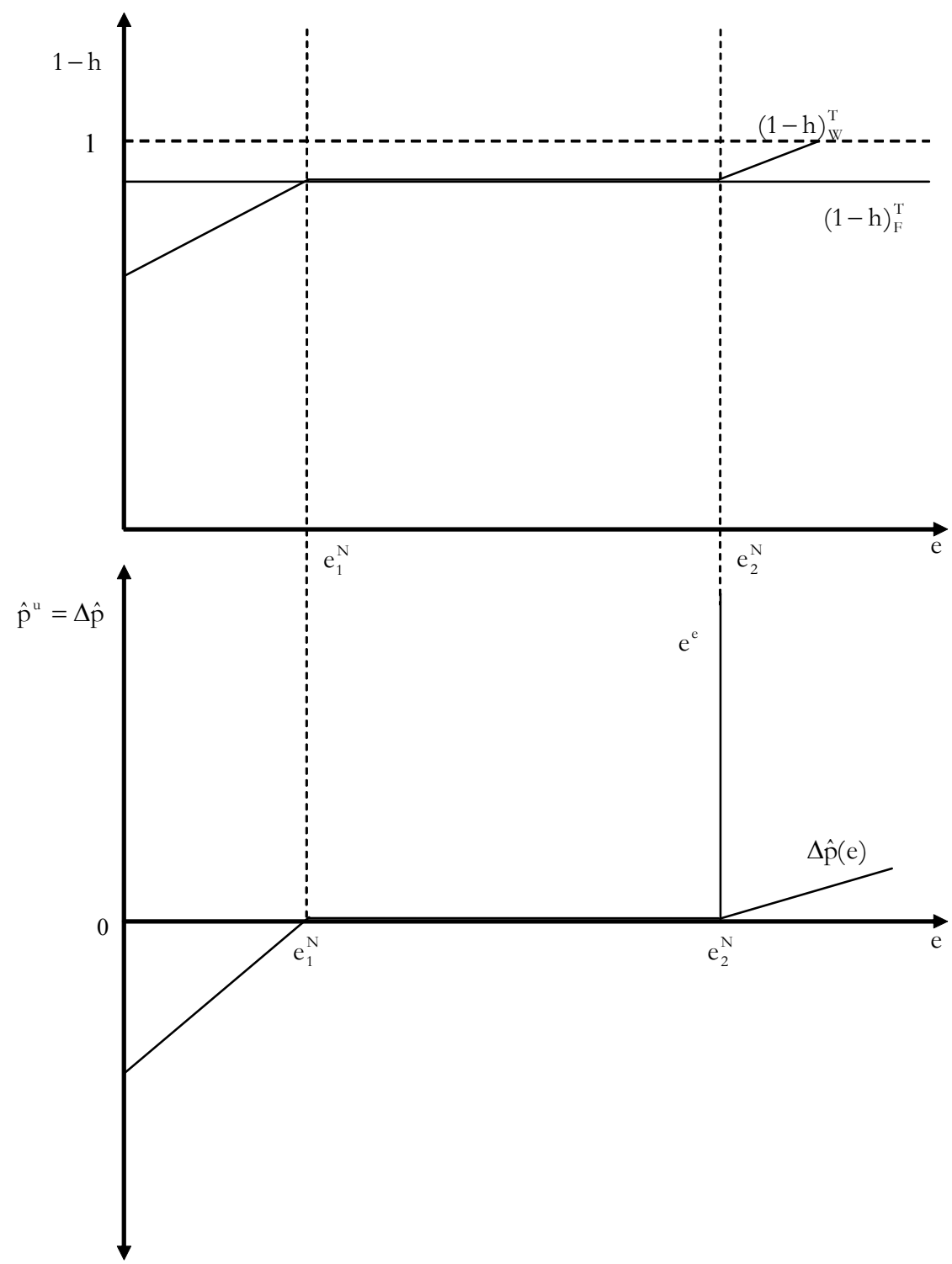

\section{$5 \quad$ Conclusions}

We have shown that, depending on the model parameters, inflation targeting monetary policies as the main stabilisation tool in the NCM may be either unnecessary, counterproductive, or limited in their effectiveness in the short run of our model. Taking into account the medium-run cost and distribution 
effects of interest rate variations renders monetary policies completely inappropriate as an economic stabiliser. Based on these results we have argued that the NCM macroeconomic policy assignment should therefore be replaced by a PK assignment. Enhancing employment without increasing inflation will be possible if macroeconomic policies are coordinated along the following lines: The central bank targets distribution between rentiers, on the hand, and firms and labourers, on the other hand, and sets low real interest rates, wage bargaining parties target inflation, and fiscal policies are applied for shortand medium-run real stabilisation purposes. 


\section{References}

Arestis, P. (1996): Post-Keynesian economics: towards coherence, Cambridge Journal of Economics, 20: $111-135$.

Arestis, P., Sawyer, M. (2003): Reinventing fiscal policy, Journal of Post Keynesian Economics, 26: 3-25.

Arestis, P., Sawyer, M. (2004a): Re-examining Monetary and Fiscal Policy for the $21^{\text {st }}$ Century, Cheltenham: Edward Elgar.

Arestis, P., Sawyer, M. (2004b): Monetary policy when money is endogenous: going beyond the 'New Consensus', in: Lavoie, M., Seccareccia, M. (eds.), Central Banking in the Modern World. Alternative Perspectives, Cheltenham: Edward Elgar.

Arestis, P., Sawyer, M. (2004c): On fiscal policy and budget deficits, Intervention. Journal of Economics, 1 (2): 61-74.

Arestis, P., Sawyer, M. (2005): Aggregate demand, conflict and capacity in the inflationary process, Cambridge Journal of Economics, 29: 959-974.

Arestis, P., Sawyer, M. (2006): The nature and the role of monetary policy when money is endogenous, Cambridge Journal of Economics, 30: 847-860.

Atesoglu, H.S., Smithin, J. (2006): Inflation targeting in a simple macroeconomic model, Journal of Post Keynesian Economics, 28: 673-688.

Ball, L. (1999): Aggregate demand and long-run unemployment, Brooking Papers on Economic Activity, 2: 189-251.

Ball, L., Mankiw, N.G. (2002): The NAIRU in theory and practice, Journal of Economic Perspectives, 16(4): 115-136.

Blanchard, O., Katz, L.F. (1997): What we know and do not know about the natural rate of unemployment, Journal of Economic Perspectives, 11(1): 51-72.

Blanchard, O., Summers, L.H. (1987): Hysteresis in unemployment, European Economic Review, 31: 288-295.

Blanchard, O., Summers, L.H. (1988): Beyond the natural rate hypothesis, American Economic Review, 78 (2): 182-187.

Carlin, W., Soskice, D. (2006): Macroeconomics. Imperfections, Institutions and Policies, Oxford: Oxford University Press.

Clarida, R., Gali, J., Gertler, M. (1999): The science of monetary policy: a New Keynesian perspective, Journal of Economic Literature, 37: 1661-1707.

Davidson, P. (2006): Can, or should, a central bank target inflation, Journal of Post Keynesian Economics, 28: 689-703.

Fontana, G., Palacio-Vera, A. (2007): Are long-run price stability and short-run output stabilization all that monetary policy can aim for?, Metroeconomica, 58: 269-298.

Gnos, C., Rochon, L.-P. (2007): The New Consensus and Post-Keynesian interest rate policy, Review of Political Economy, 19: 369-386.

Hein, E. (2002): Monetary policy and wage bargaining in the EMU: restrictive ECB policies, high unemployment, nominal wage restraint and inflation above the target, Banca Nazionale del Lavoro Quarterly Review, 55: 299-337.

Hein, E. (2004): Die NAIRU - eine post-keynesianische Interpretation, Intervention. Zeitschrift für Ökonomie, 1: 43-66.

Hein, E. (2006a): Wage bargaining and monetary policy in a Kaleckian monetary distribution and growth model: trying to make sense of the NAIRU, Intervention. Journal of Economics, 3: 305329.

Hein, E. (2006b): Interest, debt and capital accumulation - a Kaleckian approach, International Review of Applied Economics, 2006: 337-352. 
Hein, E. (2007): Money, Distribution Conflict and Capital Accumulation. Contributions to 'Monetary Analysis', Basingstoke: Palgrave Macmillan, forthcoming.

Hein, E., Stockhammmer, E. (2007): Macroeconomic Policy Mix, Employment and Inflation in a Post-Keynesian Alternative to the New Consensus Model, Department of Economics Working Paper No. 110, Vienna University of Economics and Business Administration.

Kaldor, N. (1970): The new monetarism, Lloyds Bank Review, 97: 1-17.

Kaldor, N. (1982): The Scourge of Monetarism, Oxford: Oxford University Press.

Kaldor, N. (1985): How Monetarism failed, Challenge, 28 (2): 4-13.

Kalecki, M. (1954): Theory of Economic Dynamics, London: George Allen

Kalecki, M. (1971): Selected Essays on the Dynamics of the Capitalist Economy, 1933-70, Cambridge: Cambridge University Press.

Kriesler, P., Lavoie, M. (2007): The New Consensus on monetary policy and its Post-Keynesian critique, Review of Political Economy, 19: 387-404.

Lavoie, M. (1984): The endogenous flow of credit and the post Keynesian theory of money, Journal of Economic Issues, 18: 771-797.

Lavoie, M. (1992): Foundations of Post Keynesian Economic Analysis, Aldershot: Edward Elgar.

Lavoie, M. (1995): Interest rates in post-Keynesian models of growth and distribution, Metroeconomica, 46: 146-177.

Lavoie, M. (1996a): Monetary policy in an economy with endogenous credit money, in: Deleplace, G., Nell, E. (eds.), Money in Motion, Basingstoke: Macmillan, 532-545.

Lavoie, M. (1996b): Horizontalism, structuralism, liquidity preference and the principle of increasing risk, Scottish Journal of Political Economy, 43: 275-300.

Lavoie, M. (2002): The Kaleckian growth model with target return pricing and conflict inflation, in: Setterfield, M. (ed.), The Economics of Demand-led Growth, Cheltenham: Edward Elgar.

Lavoie, M. (2004): The New Consensus on monetary policy seen from a Post-Keynesian perspective, in: Lavoie, M., Seccareccia, M. (eds.), Central Banking in the Modern World. Alternative Perspectives, Cheltenham: Edward Elgar.

Lavoie, M. (2006): A Post-Keynesian amendment to the New Consensus on monetary policy, Metroeconomica, 57: 165-192.

Layard, R., Nickell, S., Jackman, R. (1991): Unemployment. Macroeconomic Performance and the Labour Market, Oxford: Oxford University Press.

Lerner, A. (1943): Functional finance and federal debt, Social Research, 10: 38-51.

Mankiw, N.G. (2001): The inexorable and mysterious tradeoff between inflation and unemployment, The Economic Journal, 111: C45-C61.

Meyer, L.H. (2001): Does money matter?, Federal Reserve Bank of St. Louis Review, 83 (5): 1-15.

Moore, B.J. (1989): The endogeneity of credit money, Review of Political Economy, 1: 65-93.

Palacio-Vera, A. (2005): The 'modern' view of macroeconomics: some critical reflections, Cambridge Journal of Economics, 29: 747-767.

Palley, T. (2006): A Post-Keynesian framework for monetary policy: Why interest rate operating procedures are not enough, in: Gnos, C., Rochon, L.-P. (eds.), Post-Keynesian Principles of Economic Policy, Cheltenham: Edward Elgar, 78-98.

Pasinetti, L. (1981): Structural Change and Economic Growth, Cambridge: Cambridge University Press.

Pasinetti, L.L. (1974): Growth and Income Distribution, Cambridge: Cambridge University Press.

Pivetti, M. (1991): An Essay on Money and Distribution, Basingstoke: Macmillan.

Rochon, L.-P., Setterfield, M. (2007-8a): Interest rates, income distribution and monetary dominance: Post-Keynesians and the 'fair rate' of interest, Journal of Post Keynesian Economics, forthcoming.

Rochon, L.-P., Setterfield, M. (2007-8b): Post Keynesian interest rate rules and macroeconomic performance: a comparative evaluation, Journal of Post Keynesian Economics, forthcoming. 
Rowthorn, R.E. (1977): Conflict, inflation and money, Cambridge Journal of Economics, 1: 215-239.

Rowthorn, R.E. (1995): Capital formation and unemployment, Oxford Review of Economic Policy, 11(1): 26-39.

Rowthorn, R.E. (1999): Unemployment, wage bargaining and capital-labour substitution, Cambridge Journal of Economics, 23: 413-425.

Sawyer, M. (2002): The NAIRU, aggregate demand and investment, Metroeconomica, 53: 66-94.

Setterfield, M. (2004): Central banking, stability and macroeconomic outcomes: a comparison of New Consensus and Post-Keynesian monetary macroeconomics, in: Lavoie, M., Seccareccia, M. (eds.), Central Banking in the Modern World. Alternative Perspectives, Cheltenham: Edward Elgar.

Setterfield, M. (2006a): Is inflation targeting compatible with Post Keynesian economics?, Journal of Post Keynesian Economics, 28: 653-671.

Setterfield, M. (2006b): Macroeconomics without the LM curve: an alternative view, paper presented at the $9^{\text {th }}$ Post Keynesian Conference 2006, Kansas City.

Setterfield, M. (2007): Is there a stabilizing role for fiscal policy in the New Consensus?, Review of Political Economy, 19: 405-418.

Setterfield, M., Lovejoy, T. (2006): Aspiration, bargaining power, and macroeconomic performance, Journal of Post Keynesian Economics, 26: 117-148.

Smithin, J. (2004): Interest rate operating procedures and income distribution, in: Lavoie, M., Seccareccia, M. (eds.), Central Banking in the Modern World: Alternative Perspectives, Aldershot: Edward Elgar, 57-69.

Sraffa, P. (1960): Production of Commodities by Means of Commodities, Cambridge: Cambridge University Press.

Stockhammer, E. (2004): Is there an equilibrium rate of unemployment in the long run?, Review of Political Economy, 16: 59-77.

Stockhammer, E. (2008): Is the NAIRU a Monetarist, New Keynesian, Post Keynesian or Marxist theory?, Metroeconomica, forthcoming.

Wray, R. (2007): A Post-Keynesian View of Central Bank Independence, Policy Targets, and the Rules-versus-Discretion Debate, Working Paper No. 510, The Levy Economics Institute of Bard College. 
Publisher: Hans-Böckler-Stiftung, Hans-Böckler-Str. 39, 40476 Düsseldorf, Germany

Phone: +49-211-7778-331, IMK@boeckler.de, http://www.imk-boeckler.de

IMK Working Paper is an online publication series available at:

http://www.boeckler.de/cps/rde/xchg/hbs/hs.xls/31939.html

\section{ISSN: 1861-2199}

The views expressed in this paper do not necessarily reflect those of the IMK or the Hans-Böckler-Foundation.

All rights reserved. Reproduction for educational and non-commercial purposes is permitted provided that the source is acknowledged.
Hans Böckler Stiftung

Fakten für eine faire Arbeitswelt. 